\title{
The Influence of Destination and Transportation on Tourist Satisfaction and its Impact on the Loyalty of the Tourists Visiting the North Sumatera Lake Toba
}

\author{
Ferry Panjaitan \\ Doctoral Program of Management Department \\ Universitas Padjajaran \\ Bandung, Indonesia \\ ferry_hpanjaitan@yahoo.com
}

\author{
Juliater Simarmata \\ STMT Trisakti \\ Jakarta. Indonesia \\ juliaters@gmail.com
}

\begin{abstract}
The aim of this research is to examine and find out the influence of destination, transportation and tourist satisfaction on the loyalty of the tourists visiting Lake Toba both partially and simultaneously. The population in this research is all the tourists who visit Lake Toba in 2015, and the number of samples set $10 X$ indicator $(10 X 25)=250$. The data is collected through interview, questionnaire, and documentation study; the variables are studied using a 5 -score likert scale. The questionnaire is tested first using validity test and reliability test; the data processing uses the IBM software SPSS statistic 23 and it is analyzed using multiregression and path analysis. The results found in the hypothetical test of this research are as follows: partially and simultaneously, destination, transportation and tourist satisfaction significantly influence the loyalty of the tourists visiting Lake Toba. Tourist satisfaction is the variable that mediates the relationship between destination variable and transportation variable in the loyalty of the tourists visiting Lake Toba.
\end{abstract}

Keywords-Tourist, Loyalty, Destination, Transportation.

\section{INTRODUCTION}

Indonesia today has been improving its tourism industry. It is indicated with the 10 priority tourism destinations determined by the government, namely Lake Toba, Cape Kelayang, Seribu Islands, Cape Lesung, Borobudur, Bromo Tengger Semeru, Mandalika, Wakatobi, Morotai Island, Labuan Bajo. Lake Toba, one of the 10 priority Indonesian tourism destinations, is also making improvement in various things to increase the number of tourists visiting Lake Toba in North Sumatera.

In the last several years the number of visitors to Lake Toba in North Sumatera was not so great. Lake Toba is very famous with its beauty but the number of visitors is not more than those of the other domestic tourist destinations like Bali and so on. The phenomena concerning the number of visitors to Lake Toba are that the transportation to Lake Toba site is still not comfortable, such as its far distance to the airport of Kuala Namu Medan, the broken road from Medan to Lake Toba, the insufficient accommodation from the perspectives of both number and quality, and some other problems.
For tourism industry, satisfying the tourists is very important because their satisfaction is the foundation for their loyalty and recommendation for other tourists (Tornow and Wiley, 1991). Tourist loyalty is a determining key for tourism industry to operate profitably. The focus on quality tourism services will help companies in the tourism industry allocate their resources in better ways, reduce operating costs, and enhance the opportunity for setting adding-value prices which in turn will contribute to obtaining company profits (Coulter and Taylor, 1989).

\section{THEORETICAL REVIEW}

Tourist destination is a package of service and facilities with some attributes that illustrate its attractiveness $(\mathrm{Hu}$ and Ritchie, 1993). Destination image is defined as an attitude concept that consists of a number of beliefs, ideas and impressions experienced by the tourists in the destination (Hosany et al., 2006). Destination image plays a key role for destination choices, for consecutive evaluations, and for repeat destination in another time as well as recommendation in another next time (Bigné et al., 2001).

From these studies, there is a research flow which supports the vision that destination image influences the tourist satisfaction (Lee et al., 2001). Transportation is an effort to transport an object from a place to another place for a certain purpose. (Miro, 2005). Tourist satisfaction is the consequence of a post-purchasing analysis (Fornell, 1992; Westbrook and Oliver, 1991). A number of researches have shown various measurements to evaluate traveling experiences (Bramwell, 1998). These experiences explain the interaction with the services and are judgements expressed by the tourists after their experiences which can determine whether they are satisfied or unsatisfied. According to Walker, et al. (2001: 35), customer satisfaction can be defined as a condition in which customer's need, want, and expectation can be satisfied through the consumed product.

The level of tourist loyalty for a destination is reflected in their intention to review and recommend to other people (Oppermann, 2000). Thus, the information on tourist loyalty is important for the purposes of marketing and management. 


\section{Conceptual Framework}

The paradigm of this research can be illustrated in the following figure:

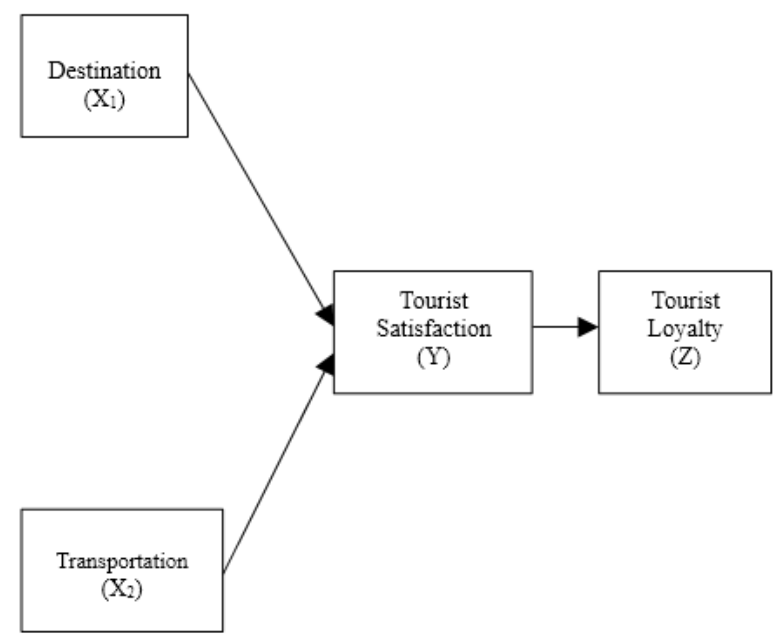

Fig. 1. Research Paradigma

\section{Research Hypotheses}

Based on the conceptual framework, the research hypotheses are formulated as follows:

1. Destination, transportation and tourist satisfaction significantly influence the loyalty of the North Sumatera Lake Toba visitors both partially and simultaneously.

2. Destination indirectly influences the loyalty of the North Sumatera Lake Toba visitors through the tourist satisfaction.

3. Transportation indirectly influences the loyalty of the North Sumatera Lake Toba visitors through the tourist satisfaction.

\section{METHODS}

\section{A. Type of Study}

The objects of this research comprise destination, transportation, and tourist satisfaction. The location of this research is the North Sumatera. The method used is descriptive-verificative method. The research method in this study uses descriptive analysis and verificative analysis. The meaning of a descriptive analysis research according to Sugiyono (2005: 1) is: the research is done to know the value of independent variable(s), either one or more independent variables without making a comparison or connecting one variable to another. In this research, descriptive analysis method is used to test each independent variable, namely tourist destination $\left(\mathrm{X}_{1}\right)$, transportation $\left(\mathrm{X}_{2}\right)$, and tourist satisfaction (Y), as well as to test the dependent variable, namely the loyalty of the tourists visiting Lake Toba (Z).

The population of this research is all the visitors to the tourism object of Lake Toba in the North Sumatera province who are domestic tourists. The sample is as many as 250 people. This number is obtained based on the determination of $10 \mathrm{X}$ indicators where there are 25 indicators in this research. The sampling technique uses accidental sampling. a research questionnaire is designed using 5-score Likert scale, and validity test and reliability test are done against the questions that have been designed.

\section{B. The Techniques for Collecting Data}

Primary data is collected through:

a. Interview using a questionnaire that has been provided before.

b. Direct interview with no questionnaire. This interview is carried out to the tourists from ASEAN countries, the leaders of tourism companies and the tourist guides in the field.

c. Observation on all the research objects in order to complete and make sure the data that has been collected from questionnaire and interview (Ginting, 2005).

Secondary data is collected through a documentaion study such as on the reports from the North Sumatera Provincial Tourism Office or Tourism Offices of related regencies.

\section{Data Analysis Method}

The method for data analysis used in this research is descriptive statistic. Descriptive statistic is a statistic used for analyzing data by describing or explaining the collected data as it is without any intention to make general conclusions. This research on the clear population will use descriptive statistic in its analysis. In a descriptive statistic there may be data presentation in tables, graphics, data distribution and percentage calculation. With the descriptive statistic we can find out the strength of relationship among variables through a correlation analysis as well as make a comparison of average data from the sample or population (Sugiyono, 2008).

Verificative analysis method is used in this research to examine the relationship among the research variables: partial test, simultaneous test, or indirect influence.

Validity test is done to all the research questions and reliability test is also done to the research variables. These tests are carried out to 30 respondents before starting the research. The results show that all the questions are considered valid and all the variables are reliable, so that the question list can be implemented for collecting the research data.

\section{RESULTS}

The test in partial shows the following results:

a. The $t$-value of destination on the loyalty of the tourists who visit Lake Toba in North Sumatera is 5.305 and the Sig. value is 0.000 . Since the $\mathrm{Sig}$ value is less than $\alpha(0.05)$, then $\mathrm{Ho}$ is rejected. It means that destination has a significant influence on the loyalty of the tourists who visit Lake Toba in North Sumatera. 
TABLE I $\quad$ T-VALUE AND SIG

\begin{tabular}{lcccll}
\hline Influence & t-value & Sig & Remarks & Conclusion \\
\hline $\begin{array}{l}\text { Destination } \\
\text { Loyalty }\end{array}$ & 5.305 & 0.000 & $\begin{array}{l}\mathrm{H}_{0} \text { is } \\
\text { rejected }\end{array}$ & Significant \\
$\begin{array}{l}\text { Transportation } \rightarrow \\
\begin{array}{l}\text { Loyalty } \\
\text { Tourist Satisfaction } \\
\rightarrow \text { Loyalty }\end{array}\end{array}$ & 4.240 & 0.001 & $\begin{array}{l}\mathrm{H}_{0} \text { is } \\
\text { rejected }\end{array}$ & Significant \\
\hline
\end{tabular}

b. The $t$-value of transportation on the loyalty of the tourists who visit Lake Toba in North Sumatera is 3.240 and the $\mathrm{Sig}$. value is 0.001 . Since the Sig value is less than $\alpha$ $(0.05)$, then Ho is rejected. It means that transportation has a significant influence on the loyalty of the tourists who visit Lake Toba in North Sumatera.

c. The $t$-value of tourist satisfaction on the loyalty of the tourists who visit Lake Toba in North Sumatera is 4.293 and the Sig. value is 0.000 . Since the Sig value is less than $\alpha(0.05)$, then Ho is rejected. It means that tourist satisfaction has a significant influence on the loyalty of the tourists who visit Lake Toba in North Sumatera.

Simultaneous test shows the F-value 56.915 and the Sig. value is 0.000 , indicating that Ho is rejected. Thus, in this case destination, transportation and tourist satisfaction simultaneously have a positive and significant influence on increasing the loyalty of the tourists who visit Lake Toba in North Sumatera.

TABLE II. F VALUE AND SIG ANOVA ${ }^{A}$

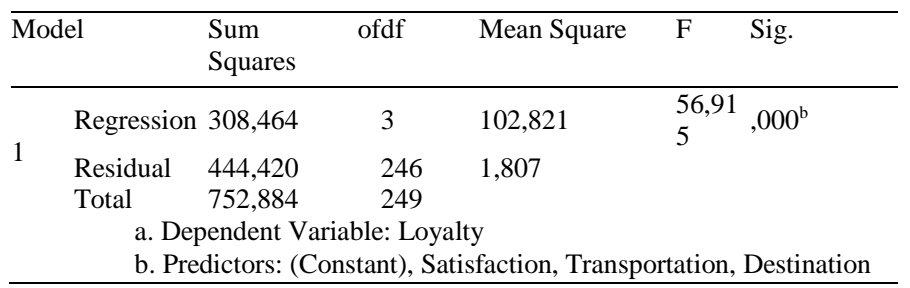

Indirect test through the tourist satisfaction is as follows:

TABLE III. DIRECT INFLUENCE AND INDIRECT INFLUENCE

\begin{tabular}{lll}
\hline Relationship & $\begin{array}{l}\text { Direct } \\
\text { Influence }\end{array}$ & $\begin{array}{l}\text { Through Tourist } \\
\text { Satisfaction }\end{array}$ \\
\hline $\begin{array}{l}\text { Destination } \rightarrow \\
\text { Loyalty }\end{array}$ & 0.358 & 0.367 \\
$\begin{array}{l}\text { Transportation } \rightarrow \\
\text { Loyalty }\end{array}$ & 0.203 & 0.248 \\
\hline
\end{tabular}

a. The direct influence of destination on the loyalty of the tourists visiting Lake Toba in North Sumatera is 0.358 whereas the indirect influence through tourist satisfaction is 0.367 , meaning that the indirect influence is bigger than the direct one, so that tourist satisfaction is the variable that mediates the influence of destination on the loyalty of the tourists visiting Lake Toba in North Sumatera.

b. The direct influence of transportation on the loyalty of the tourists visiting Lake Toba in North Sumatera is 0.203 whereas the indirect influence through tourist satisfaction is 0.248 , meaning that the indirect influence is bigger than the direct one, so that tourist satisfaction is the variable that mediates the influence of transportation on the loyalty of the tourists visiting Lake Toba in North Sumatera.

\section{CONCLUSIONS}

Based on the results of the research, the conclusions can be made as follows:

a. Destination, transportation and tourist satisfaction in partial have a positive and significant influence on enhancing the loyalty of the tourists visiting Lake Toba in North Sumatera. Simultaneously destination, transportation and tourist satisfaction have a positive and significant influence on enhancing the loyalty of the tourists visiting Lake Toba in North Sumatera.

b. Indirect test shows that tourist satisfaction is the variable that mediates the influence of destination on the loyalty of the tourists visiting Lake Toba in North Sumatera.

c. Indirect test shows that tourist satisfaction is the variable that mediates the influence of transportation on the loyalty of the tourists visiting Lake Toba in North Sumatera.

\section{REFERENCES}

Bigne, J.E., Martinez, C., Miquel, M.J., and Andreu, L., (2001), SERVQUAL reliability and Validity in travel agencies. Annal of Tourism Research. 30(1): hal. 258262.

Bramwell, B. dan Lane, B. (1998) Sustainable tourism: an evolving global approach. Journal of Sustainable Tourism, 1(1): 2

Coulter,Mary, Coulter,Ronald L., and Taylor, Rodald D. (1989) 3 Ingredients of Effective Cutomer Service Marketing,"Bank Marketing".

Ekinci, Yuksel \& Sameer Hosany. (2006). Destination Personality: An Application of Brand Personality to Tourism Destinations . Journal of Travel Research 45 page $127-140$

Fornell, C., (1992), “A National Customer Satisfaction Barometer: The Swedish Experience", Journal of Marketing, Vol. 60, pp. 7-17

Ginting, P., (2005), Pemasaran Pariwisata: Studi Empiris Tentang Kepuasan Dan Kunjungan Berkelanjutan Pariwisata Sumatera Utara. Medan: USU Press.

Hu, Y. dan Ritchie, Brent, J.R. (1993). Measuring destination attractiveness: A contextual approach. Journal of Travel Research. Vol. 32 No.3: 25-34. 
Lee, M..; Cunningham, L.F.,(2001), A costlbenefit approach to understanding service loyalty, journal of Services Marketing, vol.(15), hal.113-130

Miro, F. (2005). Perencanaan Transportasi untuk Mahasiswa, Perencana, dan Praktisi. Jakarta: Erlangga.

Stanton, Etzel, and Walker, (2001), Marketing, 12th edition, New York: Mc Graw-Hill.

Sugiyono, (2005), Metode Penelitian Bisnis, Bandung: Alfabeta.
Tornow, Walter W., and Wiley, Jack W., (1991), Service Quality and Management Practices: A look at Employe Attitudes, Customer Satisfaction, and Bottom-Line Consequences, "Human Resource Planning".

Weaver, D. and Oppermann, M. (2000). Tourism Management. Brisbane: John Wiley \& Sons.

Westbrook, R.A., and R.L. Oliver. (1991), "The Dimensionality of Consumption Emotion Patterns and Consumer Satisfaction," Journal of Consumer Research, Vol. 18 (Juni), pp. 84-91. 